УДК 633.522: 631.53.01

DOI https://doi.org/10.32851/tnv-tech.2021.5.4

\title{
АНАЛІЗ ОРГАНОЛЕПТИЧНИХ ПОКАЗНИКІВ ЯКОСТІ ХЛІБА ПШЕНИЧНОГО 3 ПІДВИЩЕНОЮ ХАРЧОВОЮ ЦІННІСТЮ
}

\author{
Резвих Н.I. - кандидат технічних наук, \\ доцент кафедри інженерії харчового виробництва \\ Херсонського державного аграрно-економічного університету \\ ORCID ID: 0000-0002-4727-512X
}

У статті висвітлено найважливіші завдання, які стоять перед харчовою промисловістю Украӥни.

Проаналізовано наукові роботи, присвячені дослідженню впливу різних видів сировини на органолептичні показники якості хліба пшеничного.

Досліджено роботи вчених, спрямовані на вивчення впливу рослинних жирів та олій на організм людини і визначення норм їх споживання у щзоденному раціоні, розкрито їхню роль в життєдіяльності організму.

Проаналізовано наукову літературу та результати вітчизняних $і$ закордонних досліджень з визначення харчової та біологічної цінності насіння конопель як сировини для одержання рослинної олії. Проведений аналіз харчової та біологічної иінності насіння конопель показав, шо воно містить 25\% білка, 31\% жирів та 34\% вуглеводів. У складі конопляного насіння є 20 амінокислот, з яких 8 незамінних (вони не синтезуються в організмі людини). В конопляному насінні міститься велика кількість вітамінів $E, C$, Д, $K$, вітаміни групи $B$, а також каротиноїди (попередники вітаміну А), макро- $і$ мікроелементи (залізо, магній, калій, фосфор, кальиій, марганець, иинк, сірка, хлор тощо).

Досліджено вплив конопляної олії, що додавалась у різних дозуваннях у рецептуру хліба пшеничного, на його якість з метою отримання дієтичного та оздоровчого продукту з підвищеною харчовою циінністю завдяки вмісту ненасичених жирних кислот у конопляній олії.

Розроблено реиептуру та здійснено оцінку органолептичних показників якості хліба пшеничного, досліджено зміну цих показників.

В результаті дослідження органолептичних показників якості хліба пшеничного, виготовленого з різним дозуванням конопляної олії в рецептурі, встановлено, щяо якість пшеничного хліба за додавання 34-68 г конопляної олії не погіршується, а залишається високою. Збільшення конопляної олії до понад 68 г у рецептурі призводить до погіршення смаку, кольору, скоринки хліба. Таким чином, у виробництві хліба пшеничного з конопляною олією можна використовувати олію в кількості до 68 г .

Ключові слова: олія конопляна, хлібопекарська продукиія, хліб.

Rezvykh N.I. Analysis of organoloptic qulity indicators of wheat bread whith hight nutritional value

The article provides information on the most important tasks facing the food industry of Ukraine.

The scientific works devoted to research of influence of various kinds of raw materials on organoleptic indicators of quality of wheat bread are analyzed.

The researches of the scientists directed on studying of influence of vegetable fats and oils on a human body and definition of norms of their consumption in a daily diet are analyzed, their role in vital activity of an organism is specified.

The scientific literature and the results of domestic and foreign studies to determine the nutritional and biological value of hemp seeds as a raw material for vegetable oil are analyzed. An analysis of the nutritional and biological value of hemp seeds showed that it contains $25 \%$ protein, $31 \%$ fat and $34 \%$ carbohydrates. Hemp seeds contain 20 amino acids, of which 8 are essential (they are not synthesized in the human body). Hemp seeds contain a large number of vitamins $E, C, D, K, B$ vitamins, as well as carotenoids (precursors of vitamin A), macro-and micronutrients (iron, magnesium, potassium, phosphorus, calcium, manganese, zinc, sulfur, chlorine, etc.).

The influence of hemp oil, which was added in different dosages to the recipe of wheat bread, on its quality in order to obtain a valuable product with high nutritional value, dietary and health nature due to the content of unsaturated fatty acids in hemp oil was studied. 
The recipe is developed and the assessment of organoleptic indicators of wheat bread quality is carried out and the change of its organoleptic quality indicators is investigated.

As a result of the study of organoleptic quality indicators of wheat bread made with different dosages of hemp oil in the recipe, it was found that the quality of wheat bread with the introduction of hemp oil in the amount of 34-68 g does not deteriorate, but remains high. An increase in hemp oil above $68 \mathrm{~g}$ in the recipe leads to a deterioration of its taste, color, crust. Thus, in the production of wheat bread with hemp oil, you can use oil in quantities up to $68 \mathrm{~g}$.

Key words: hemp oil, bakery products, bread.

Вступ. Найважливішими завданнями харчової промисловості України в сучасних умовах, згідно з Наказом Міністерства аграрної політики України «Про затвердження галузевої програми розвитку хлібопекарської галузі на період до 2015 р.» від 20 березня 2008 р. № 164, є, по-перше, забезпечення всіх верств населення якісною продукцією відповідно до фізіологічних норм харчування, яка покращує стан здоров'я та подовжує термін життя; по-друге, підвищення конкурентоспроможності хлібопекарської галузі, подолання кризових явищ, забезпечення іiі економічної стабільності і подальшого ефективного розвитку; по-третє, виробництво хлібобулочних виробів профілактичного призначення групи «Здоров'я», які характеризуються підвищеною харчовою цінністю, збільшеним вмістом харчових волокон, вітамінів, мінеральних речовин, протеїнів, антиоксидантів [1].

Постановка проблеми. Проведені науковцями дослідження з вивчення впливу рослинних жирів на організм людини та визначення норм їх споживання у щоденному раціоні показали, що рослинні жири відіграють значну роль в життедіяльності організму. Також було визначено ступінь участі рослинних жирів у пластичних процесах організму та їх нормування в харчуванні.

3'ясовано, що особливе значення мають поліненасичені жирні кислоти: лінолева, ліноленова, арахідонова, що не синтезуються в організмі людини. Роль цих жирних кислот полягає в тому, що вони беруть участь в утворенні гормоноподібних речовин, які впливають на регуляцію обмінних процесів.

Рослинні жири є важливим джерелом вітамінів А, Е, Д, які позитивно впливають на функціонування кісткової тканини, розвиток організму та імунні процеси [2].

Аналіз наукової літератури та вітчизняних і закордонних джерел інформації з визначення харчової та біологічної цінності насіння конопель як сировини для одержання рослинної олії довів, що воно має унікальний амінокислотний склад. Так, дослідження насіння 10 канадських провідних сортів конопель, проведені вченими, показали, що вміст жирів у них становить 26,9-30,6\%, а білків $23,8-28 \%$. Вивчення вченими жирнокислого складу конопляної олії, одержаної 3 насіння конопель, показало, що вона складається переважно з ненасичених жирних кислот. Вміст лінолевої кислоти (Омега-6) становить 59,7\%, а-ліноленової (Омега-3) - 17\%. В усіх десяти сортах $\gamma$-токоферол був присутній у значно вищій концентрації, ніж $\delta$-токоферол (2481 мг/г порівняно з 774 мг/г); вміст фенолів становив 1,37-5,16 г/100 г; концентрація - від 25,9 до 38,8\%. Українським ученим Н.А. Совою вперше був проведений аналіз із визначення жирнокислого складу олії з конопель українського сорту «Глесія», в результаті якого було з'ясовано, що вона містить 54,8-55\% лінолевої (Омега-6), 16,2\% олеїнової (Омега-9), 14,7-14,8\% а-ліноленової (Омега-3) та 2,3\% гамма-ліноленової (Омега-6) кислот [3].

Отже, проведені закордонними та вітчизняними вченими наукові дослідження показали, що насіння конопель й одержана з нього конопляна олія містять гамма-ліноленову кислоту, яка досить рідко зустрічається в рослинній сировині, та унікальні ненасичені жирні кислоти, порівняно з відомими рослинними оліями, зокрема соняшниковою, та є збалансованими продуктами для здоров’я людини. 
У зв'язку з негативним впливом на стан здоров'я та тривалість життя людей нинішньої екологічної ситуації в Україні постає необхідність у забезпеченні населення нашої держави якісною продукцією відповідно до фізіологічних норм харчування, яка покращує стан здоров'я, сприяє нормальному функціонуванню організму людини та подовжує тривалість життя.

Досягти цього можна завдяки ефективному поповненню раціону людини, який наразі характеризується недостатнім вмістом вітамінів і мінеральних речовин, що надходять з їжею, та продуктами масового споживання, за допомогою збагачення харчування, зокрема і хліба, цими нутрієнтами. Оскільки хліб є щоденним продуктом харчування, дедалі частіше споживачі віддають перевагу його натуральному рецептурному складу та відсутності харчових добавок.

Сьогодні в Україні для виготовлення хліба разом із традиційною використовують і нетрадиційну сировину, яка впливає на органолептичні показники одержаного хлібопекарського виробу, а саме на зміну смаку, запаху та аромату хліба, а ще надає хлібу необхідні для людини властивості, покращує його харчову цінність. Підвищити харчову цінність продукту, його безпечність 3 погляду збалансованого харчування можна завдяки використанню конопляної олії для виготовлення хліба, замінивши соняшникову олію в рецептурному складі, оскільки конопляна характеризується високим вмістом ненасичених жирних кислот і вітамінів.

Багато робіт присвячено дослідженням впливу різних видів сировини на органолептичні показники якості хліба пшеничного. Так, українськими вченими Н.О. Фалендиш та Ю.В. Бадрук встановлено, що завдяки додаванню конопляного борошна й олії відбувається збагачення хліба незамінними амінокислотами, мінеральними речовинами, харчовими волокнами та поліненасиченими жирними кислотами групи $\omega 3 \mathrm{i} \omega 6$. Додавання конопляного борошна сприяє також підвищенню газоутворювальної здатності тіста та кислотонакопичення, що дозволяє скоротити тривалість його дозрівання на 5-22 хв. Конопляне борошно поліпшує формостійкість тіста завдяки збільшеному вмісту клітковини, пентозанів і лецитину. Хліб, що містить конопляне борошно та олію, має приємний конопляний смак й аромат, темнозабарвлену м'якушку з зеленуватим відтінком [4].

Тому вивчення впливу конопляної олії на якість хліба пшеничного з метою отримання дієтичного та оздоровчого продукту з підвищеною харчовою цінністю завдяки вмісту ненасичених жирних кислот $є$ актуальним завданням.

Метою дослідження $\epsilon$ розробка рецептури та оцінка органолептичних показників якості хліба пшеничного функціонального призначення.

В результаті дослідження було з'ясовано вплив різних дозувань конопляної олії, яка додавалася до рецептури хліба пшеничного, на зміну його органолептичних показників якості.

В роботі визначали якість виготовлених зразків хліба пшеничного $з$ додаванням конопляної олії за органолептичними показниками.

Виклад основного матеріалу. Об'єктами дослідження стали такі зразки хліба пшеничного: 1 - контрольний, виготовлений за традиційною рецептурою; 2 - із додаванням конопляної олії; 3 - із додаванням удвічі більшого дозування конопляної олії; 4 - із додаванням утричі більшого дозування конопляної олії. Для визначення впливу олії на показники якості хліба пшеничного проводили пробне випікання за загальноприйнятою методикою наукових досліджень в лабораторії здорового харчування кафедри інженерії харчового виробництва Херсонського державного аграрно-економічного університету. 
У процесі виробництва хліба використовували такі інгредієнти: борошно пшеничне вищого сорту (600 г); дріжджі пресовані (6 г); сіль кам'яну (5 г); олію конопляну (34 г); цукор (24 г), воду (370 г).

Для визначення органолептичних показників якості дослідних зразків хліба пшеничного з додаванням конопляної олії застосовували загальноприйняті методики і нормативні документи: ДСТУ 7044:2009 «Вироби хлібобулочні. Правила приймання, методи відбирання проб, методи визначання органолептичних показників і маси виробів» та ДСТУ 7517:2014 «Хліб із пшеничного борошна. Загальні технічні умови» $[5 ; 6]$.

Для візуалізації та більш повного уявлення про стан м'якушки було здійснено дослідження структури зразків хліба пшеничного, отриманого за новими рецептурами (табл. 1).

Всі дослідні зразки хліба пшеничного були виготовлені з пшеничного борошна вищого сорту.

Склад хліба пшеничного корисний, але поява інноваційних інгредієнтів спонукає до проведення нових досліджень. Тому одним із завдань роботи було розроблення рецептури хліба пшеничного з додаванням конопляної олії, яка є джерелом всіх незамінних амінокислот.

Прототипом обрано найпоширенішу за використанням в Україні рецептуру хліба пшеничного на основі соняшникової олії.

Рецептуру дослідних зразків хліба пшеничного наведено в табл. 1.

Таблиця 1

Рецептура дослідних зразків хліба пшеничного

\begin{tabular}{|l|c|c|c|c|}
\hline \multirow{2}{*}{$\begin{array}{l}\text { Найменування рецептурних } \\
\text { компонентів }\end{array}$} & \multicolumn{4}{|c|}{ Витрати сировини на 100 г готової продукції, г } \\
\cline { 2 - 5 } & Зразок 1 & Зразок 2 & Зразок 3 & Зразок 4 \\
\hline $\begin{array}{l}\text { Борошно пшеничне вищого } \\
\text { сорту }\end{array}$ & 60 & 60 & 60 & 60 \\
\hline Цукор-пісок & 2,4 & 2,4 & 2,4 & 2,4 \\
\hline $\begin{array}{l}\text { Олія соняшникова } \\
\text { нерафінована }\end{array}$ & 3,4 & - & - & - \\
\hline Олія конопляна нерафінована & - & 3,4 & 6,8 & 10,2 \\
\hline Сіль & 0,5 & 0,5 & 0,5 & 0,5 \\
\hline Вода & 37 & 37 & 37 & 37 \\
\hline Дріжджі & 0,5 & 0,5 & 0,5 & 0,5 \\
\hline
\end{tabular}

Під час визначення показника зовнішнього вигляду перевіряли відповідність виготовленого хліба пшеничного формі, в якій проводили випікання. Згідно з нормативними документами виготовлений хліб пшеничний повинен мати випуклу верхню скоринку з відсутністю бокових напливів.

Показник поверхні хліба пшеничного оцінювали візуально, визначали гладкість або шорсткість, наявність чи відсутність на поверхні хліба забруднень, надколів, надрізів, посипки, тріщин.

Забарвлення скоринки було оцінене за ступенем іiі інтенсивності. Виготовлені зразки хліба пшеничного розрізали ножем на дві рівні частини, при цьому звертали увагу на колір м'якушки та іiї відтінки. Колір м'якушки визначали за денного освітлення, допускається градація кольору від світло-жовтого до темнокоричневого; встановлювали також наявність підгорілості скоринки. Відзначали 
і рівномірність забарвлення та стан м'якушки. Згідно зі стандартами м'якушка має бути пропечена, еластична, неволога на дотик, з розвинутою пористістю, без слідів непромісу й ущільнення. Від стану м'якушки залежить те, наскільки повно і швидко хліб, що потрапить до шлунку та кишечника людини, буде засвоюватися iï організмом.

Таблиця 2

Результати дослідження показників зовнішнього вигляду зразків хліба пшеничного з підвищеною харчовою цінністю

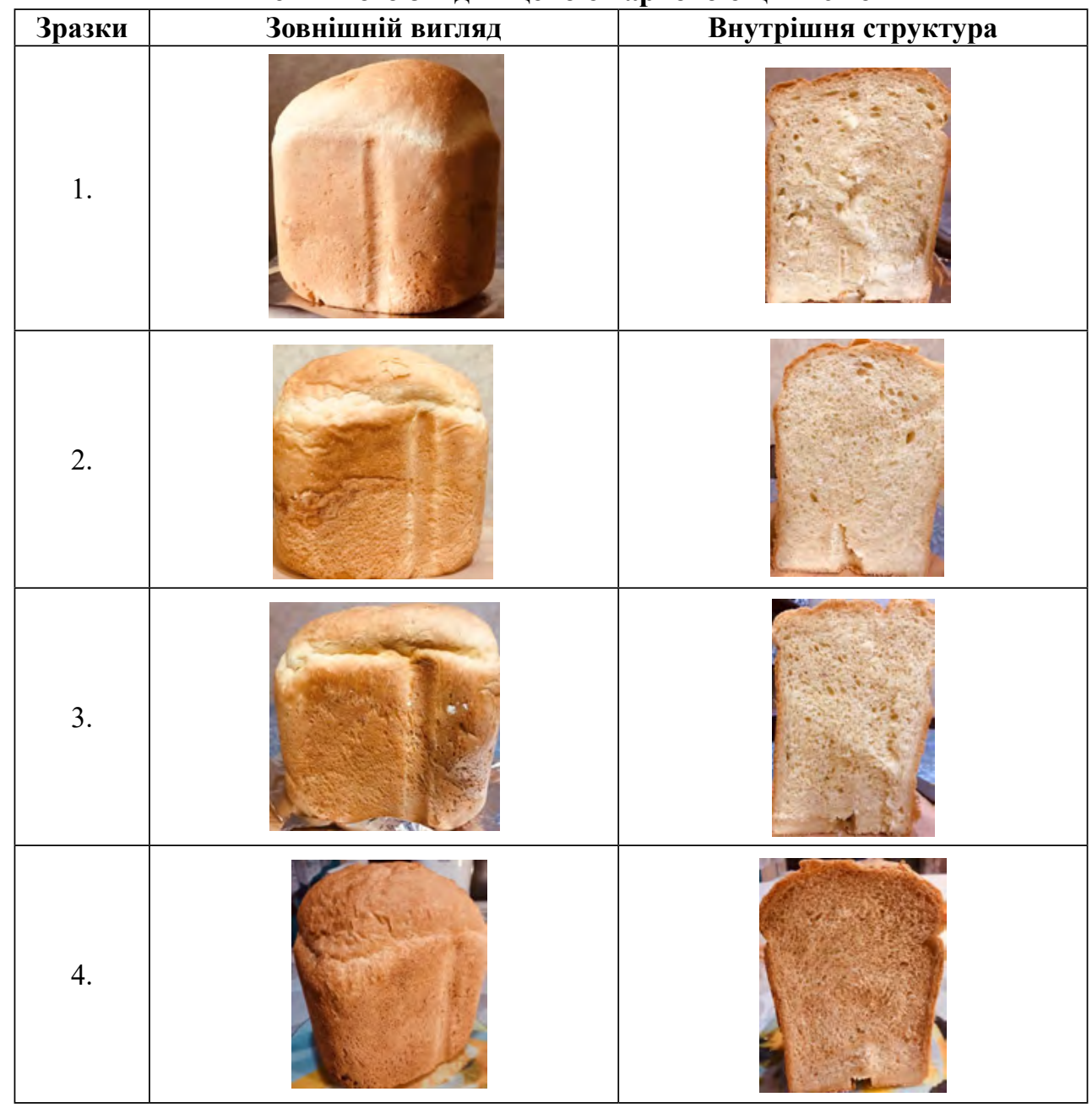

Аромат (запах) і смак визначали під час проведення дегустації хліба. При цьому критеріями оцінки аромату та смаку були характерність (специфічність для певного рецептурного варіанта) і ступінь виразності цих показників. Запах і смак визначали розжовуванням хліба. Смак і запах може бути нормальним, кислим, прісним, гіркуватим або зі стороннім, що не властивий цьому виду виробу, присмаком. Хрускіт свідчить про наявність у хлібі мінеральних домішок. Розжовування визначається також під час дегустації. 


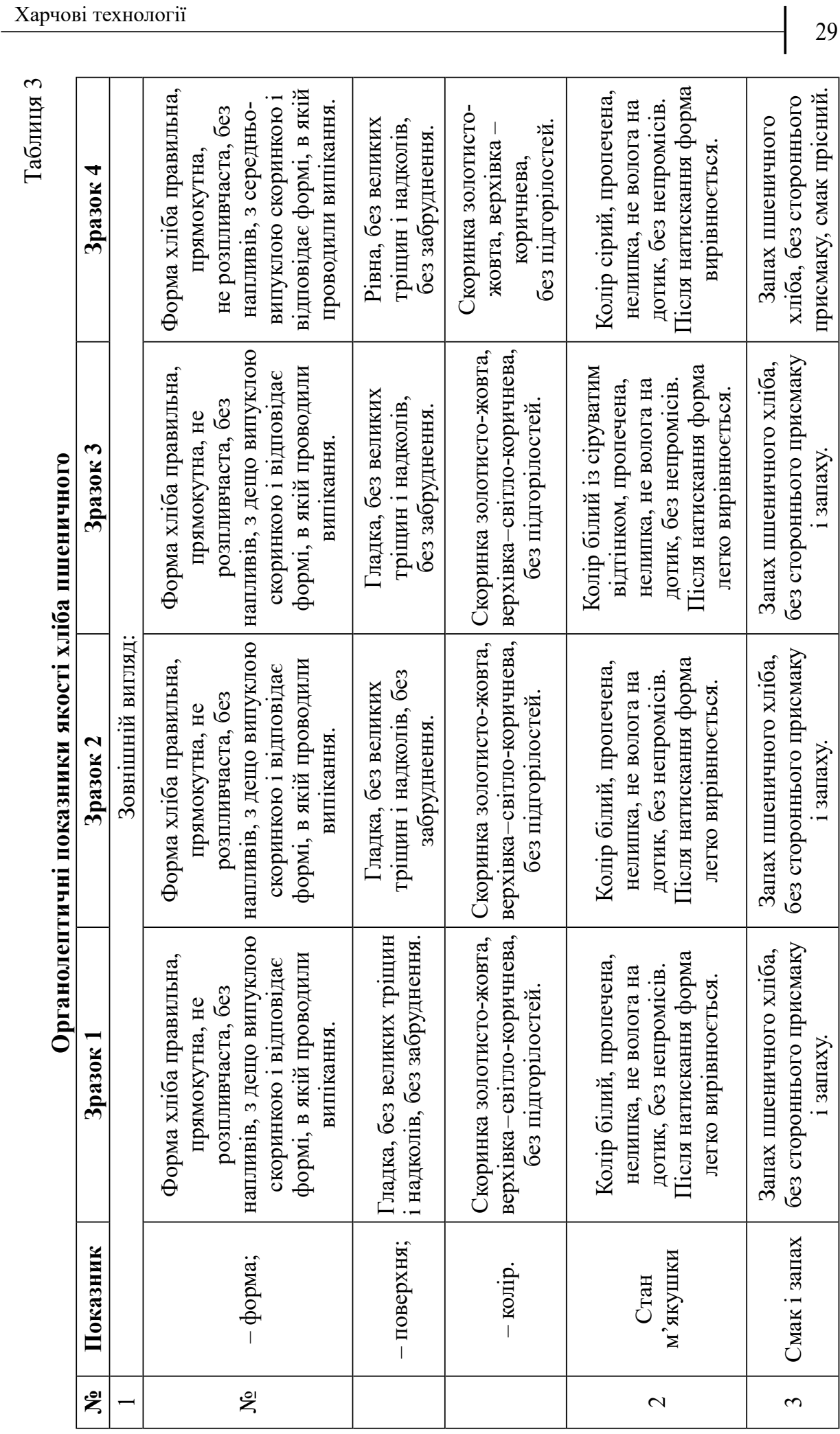


При цьому звертають увагу на грудкуватість, соковитість або сухість, ніжність або твердість, крихкість або клейкість м'якушки. У хлібі не допускаються сторонні включення, хрускіт від мінеральної домішки, ознаки хвороб. Стороннє включення - це включення в м'якушці хлібобулочного виробу, яке видно візуально та яке $\epsilon$ небезпечним для життя і здоров'я людини. Хрускіт від мінеральної домішки - хруст, який з'являється під час розжовування. Результати дослідження органолептичних показників якості зразків хліба пшеничного з підвищеною харчовою цінністю наведені в табл. 3 .

У дослідних зразків хліба стан м'якушки характеризується як помірно великий та рівномірний. Колір м'якушки дослідних зразків - від білого, білого з сіруватим відтінком до сірого. Під час проведення досліджень дефектів смаку та запаху нами не виявлено. Таким чином, всі зразки хліба відповідали вимогам ДСТУ 7517:2014 «Хліб із пшеничного борошна. Загальні технічні умови», жоден зразок не мав дефектів форми.

За результатами досліджень органолептичних показників якості хліба пшеничного $з$ додаванням конопляної олії встановлено, що дослідні зразки хліба пшеничного мають прямокутну форму, не розпливчасту, без напливів, відповідають формі, в якій проводили випікання. Скоринка хліба пшеничного у зразках 1, 2 і 3 не змінилася та залишилася випуклою, а в 4 зразку хліба пшеничного випуклість охарактеризували як середню. Стан поверхні скоринки у зразках 1, 2 і 3 додаванням конопляної олії не змінився - залишився гладким, без тріщин, надколів і забруднення, а у зразку 4 його охарактеризували як рівний.

Колір скоринки у зразках 1, 2 і 3 світло-коричневий. Таким чином, під час дослідження було встановлено, що збільшення втричі дозування конопляної олії призводить до погіршення кольору скоринки.

Зі збільшенням дозування конопляної олії в рецептурі хліба пшеничного спостерігаються зміни й у характеристиці м'якушки. Зокрема, у зразку 2 за додавання до рецептури 34 г конопляної олії отримуємо білий колір м'якушки. Колір м'якушки стає білим із сіруватим відтінком в разі збільшення дозування конопляної олії вдвічі. Збільшення додавання конопляної олії втричі призводить до погіршення кольору м'якушки, вона стає сірою.

Еластичність м'якушки в усіх досліджуваних зразках хліба пшеничного, незалежно від кількості внесеної конопляної олії, дуже гарна, після натискання форма легко вирівнюється, поверхня хліба пропечена, нелипка, не волога на дотик, без непромісів.

Смак пшеничного хліба за додавання конопляної олії та в разі збільшення іiі вдвічі залишається пшеничним, без стороннього присмаку, а в разі збільшення ії втричі смак стає прісним.

Висновки. Як відомо, конопляна олія є джерелом всіх незамінних амінокислот. В результаті дослідження органолептичних показників якості хліба пшеничного, виготовленого на основі конопляної олії, встановлено, що якість пшеничного хліба за додавання 34-68 г конопляної олії не погіршується, а залишається високою. Збільшення конопляної олії до понад 68 г призводить до погіршення смаку, кольору, скоринки. Таким чином, у виробництві хліба пшеничного 3 конопляною олією можна використовувати олію в кількості до 68 г .

Використання конопляної олії у виробництві дозволить розширити асортимент хліба та хлібобулочної продукції, дасть змогу розробити і впровадити хлібобулочні вироби оздоровчого, профілактичного, дієтичного харчування для різних вікових груп та зон екологічного неблагополуччя. 
Завдяки виробництву хліба пшеничного з додаванням конопляної олії населення України буде забезпечене повноцінною високоякісною хлібопекарською продукцією відповідно до фізіологічних норм харчування різних верств населення, що збільшить щоденне надходження незамінних компонентів харчування, позитивно впливатиме на стан здоров'я людей і тривалість їхнього життя.

\section{СПИСОК ВИКОРИСТАНОӤ ЛІТЕРАТУРИ:}

1. Про затвердження галузевої програми розвитку хлібопекарської галузі на період до 2015 р. : Наказ Міністерства аграрної політики України від 20 березня 2008 p. № 164. URL: http://www.uazakon.com/documents/date_e3/pg_gtcywj.htm.

2. Товарознавство і стандартизація продукції безнаркотичної коноплі : монографія / Л.А. Чурсіна та ін. ; за заг. ред. Л.А. Чурсіної. Херсон : ПП Вишемирський В.С., 2012. 308 с.

3. Сова Н.А. Технологія комплексної переробки насіння промислових конопель : дис. ... канд. техн. наук : 05.18.02. Херсон, 2019. 330 с.

4. Хліб «Конопляний» : пат. 120719 Україна: A21D 13/00/. № u 201705908 ; заявл. 13 червня 2017 р.; опубл. 10 листопада 2017 р., Бюл. № 21.4 с.

5. Вироби хлібобулочні. Правила приймання, методи відбирання проб, методи визначання органолептичних показників і маси виробів : ДСТУ 7044:2009. URL: https://dnaop.com/html/33865/doc-\%D0\%94\%D0\%A1\%D0\%A2\%D0\%A3_7044_ 2009 (дата звернення: 22.12.2019 р.).

6. Хліб із пшеничного борошна. Загальні технічні умови : ДСТУ 7517:2014. URL: http://online.budstandart.com/ua/catalog/doc-page.html?id_doc=77546 (дата звернення: 22.12.2019 р.).

\section{REFERENSES:}

1. Nakaz Ministerstva ahrarnoyi polityky Ukrayiny "Pro zatverdzhennia haluzevoy prohramy rozvytku khlibopekarskoy haluzy na peryod do 2015 g." vid 20.03.2008 g. № 164 [Order of the Ministry of Agrarian Policy of Ukraine "On the closure of the sectoral program for the development of the bakery industry for the period up to 2015" from 20.03.2008 № 164]. URL: http://www.uazakon.com/documents/date_e3/pg gtcywj.htm. [in Ukrainian]

2. Chursina, L.A., Bogdunova, O.F., Lulina, N.P., Rezvykh, N.I. (2012) Tovarovedeniye i standartizatsiya produktsii beznarkoticheskoy konopli : monografiya [Commodity science and standardization of narcotic cannabis products : Monograph]. Kherson : PP Vishemirsky V.S.

3. Sova, N.A. (2019) Technology of complex processing of seeds of industrial hemp. Extended abstract of candidate's thesis. Kherson : HNTU. [in Ukrainian]

4. Falendish, N.O., Badruk, U.V. Khlib "Konoplyanyy" pat. № 120719 Ukraina, A21D 13/00 ; № u201705908; zajavl. 13.06.2017; opubl. 10.11.2017. Bjul. № 21 . [Bread "Hemp": US Pat. № 120719 Ukraine, A21D 13/00/; № u201705908; declared 13.06.2017; publ. 10.11.2017 Bull. № 21.].

5. Vyroby khlibobulochni. Pravyla pryymannya, metody vidbyrannya prob, metody vyznachannya orhanoleptychnykh pokaznykiv i masy vyrobiv : DSTU 7044:2009. [Bakery rules of acceptance, methods of sampling, methods of determination of organoleptic indicators and weight of products: DSTU 7044: 2009]. URL: http://dnaop.com/ $\mathrm{html} / 33865 /$ doc-\%D0\%94\%D0\%A1\%D0\%A2\%D0\%A3_7044_2009. [in Ukrainian]

6. Khlib iz pshenychnoho boroshna. Zahalni tekhnichni umovy : DSTU 7517:2014 [Bread from wheat flour. General technical conditions: DSTU 7517:2014]. URL: http://online.budstandart.com/ua/catalog/doc-page.html?id_doc=77546. [in Ukrainian] 